\title{
The Implementation of Voluntary Land Donation (LDV) and Community-Driven Development (CDD) Program:Lesson from ICWRMIP Project in Indonesia
}

\author{
Pius Suratman Kartasasmita \\ Department of Public Administration \\ Faculty of Social and Political Sciences, \\ Catholic University of Parahyangan, Bandung. \\ pius@unpar.ac.id
}

\begin{abstract}
The ICWRMIP is an ADB funded project carried out by the Government of Indonesia represented by Ministry of Health. The projectincludes support for Community and NGO-Driven Initiatives for Improved Water Supply and Sanitation which requires the implementation of voluntary land donation (VLD) referring to a process of giving up individual or community rights on land for public usage voluntarily. This study deals withthe extent to which procedures and principles of VLDareimplemented at community level andthe extent to which the land utilization for community infrastructures could sustained beyond project closure. Quantitative approach is used as a basic design in conducting community profiling. However, qualitative approach is used to finalizepost-project evaluation. Thirty-two (32) from fifty-four (54) initiated projects were selected as sample using two-stage random sampling. Field survey, documentary study, depth interview and observationon physical projectwere combined as data collection techniques. The study concludes, that the procedures and principles of VLD agreedby both ADB and GOI are well implemented in terms of information clarity, public participation and consultation, as well as gender equality treatment. It is unexpectedly found that most of the donated land are belong to vulnerable group as measured by their education, occupation, income and expenditures. The study also confirmed that VLD used for community infra-structures, is doubtfully sustained beyond project closure due to five identified factors:unclear legal document of land ownership, conflicting status of the donated land, discontinuity of long term benefit ofthe projects, and incompleteinstitutionalization processes.
\end{abstract}

Keywords: Voluntary Land Donation (VLD), Community-Driven Development (CDD), ICWRMIP, Asian Development Bank (ADB), Government of Indonesia.

\section{INTRODUCTION}

The Integrated Citarum Water Resource Management Investment Program (ICWRMIP) is an Asian Development Bank (ADB) funded project that was carried out by the Government of Indonesia (GOI), implemented by the Ministry of Health. The project is implementing in tranches over a period of 15 years. Among othercomponents, the project includes the Support for Community and NGO-Driven Initiatives for Improved Water Supply and Sanitation (Sub-component 2.3) which requires a community-driven approach. This subcomponent aims to provide the community with adequate amounts of accessible clean water, and additional financing for other health related activities of their choosing. This included an opportunity for individual households to construct private sanitation facilities or for the community to build simple solid waste disposal or waste water drainage, or to finance other kinds of health support services as they may choose. Construction of water systems, communal sanitation and solid waste disposal be done by villagers through self-help, in which non-local material (e.g. pipes, pumps, etc.) financed by the project. The villages will co-finance with a $20 \%$ up-front contribution consisting of $4 \%$ of the total construction cost in cash, and an additional $16 \%$ in labour and local materials. Operation and Maintenance system will be the responsibility of the community with 
institutional support made available for difficult problems which might arise. The land required for constructed project infrastructures were community responsibility as beneficiaries. It could be derived from: (i) individual with conditions; (ii) village which is social facility land; (iii) institution, as if the land belongs to PJT-2 (ADB, 2014).

This study deals with two research questions. Firstly, the extent to which the setVLD procedures and principles, which are internationally designed by Asian Development Bank (ADB) and agreed by the Government of Indonesia (GOI) as part of loan agreement, were locally implemented at community level. Secondly, the extent to which the donated and utilized land for community infrastructures could sustain beyond the project closure. These two leading questions are conceptualized within the framework of Community-Driven Development (CDD).

\section{CONCEPTUAL FRAMEWORK Community - Driven Development (CDD)}

Community-driven development (CDD), is defined as a development program that uses approach and gives control over planning decisions and investment resources to community groups and local governments. It is commonly considered and embraced by donors as an effective program-based approach to delivering international development aid in the last decade. It is believed that CDD provides communities with a voice and control over all project stages, at least in three important aspects; complement market and public activities, enhance sustainability, and improve project effectiveness and efficiency (Asante, 2012). Wide-range of experience has shown that development policies aimed at promoting national economic competitiveness and state run public investment programs are essential, but insufficient for poverty reduction. The benefits often take years to trickle down. CDD offers the opportunity to fill this critical gap by achieving immediate and lasting results at the grassroots level. It is empirically proven that CDD makes public services responsive to demand expressed by the poor which enhance sustainability. Exemplary evidence regarding water supply project, exhibits from 1.875 households in rural communities in Benin, Bolivia, Honduras, Indonesia, Pakistan, and Uganda, suggests that water system sustainability is significantly higher when communities control key investment decisions and when they becoming part of the investment costs. The demand is better articulated when communities contribute to investment costs and control investment choices (Katz, 2003).

In the context of poverty alleviation efforts, it is shown that CDD allows poverty reduction efforts to be taken to scale. CDD devolves responsibilities and resources to the local level and activities can occur simultaneously in a large number of communities without being constrained by a central bureaucracy. When poor communities are trusted to drive development and are given appropriate information, support and clear rules, a system can be put in place not to provide for poor people, but to facilitate their ongoing role in rolling out poverty reduction efforts. It is proven that CDD makes development more inclusive of the interest of poor and vulnerable groups. Representative of CBOs can provide voice and empowerment to groups that are normally excluded from the development process. The minority groups, for example, might not be effectively expressed through standard political and economic structures.

In short, CDD is a justifiable conceptual framework, deeply-rooted in the field of community developmentwhich is defined as a planned evolution of all aspects of community well-being (economic, social, environmental and cultural). It is a process whereby community members come together to take collective action and generate solutions to common problems. An effective community development, therefore, should be a long-term endeavor, well planned, inclusive and equitable, holistic and integrated into the bigger picture, initiated and supported by community members, benefit to the community and grounded in experience that leads to best practice. The primary outcome of community development, therefore, is improved quality of 
live (Smith, 1999). In other words, community development ultimately focuses on the centrality of oppressed people in the process of overcoming externally imposed social problems (Tan, 2009).Community development is a bottom upmechanism embedded and becoming a solid identity of community planning and execution. It is considered as the most viable alternative to the generally used top down approach in implementing governmental programs and policies. In the past, bottom up approach was never reached the grass root level indicating no involvement of the community as a whole, such as in the decision making process. It is commonly recognized that participation in government schemes often means no more than using the service offered or providing inputs to support the project. Currently CDD is transforming itself from trivial to the heart of development approach, both in theory and practice (Mathbor, 2008).

\section{Voluntary Land Donation (VLD)}

In order to build conceptual framework regarding "voluntary land donation" which is rarely found in the body of literature compare to "land acquisition", this study takes a liberty to use the later as the point of departure referring to a process used by the state is contested for years on ground of 'eminent domain' and 'public purpose' for private industries (Sridhar, 2016). So that VLD as viewed from the opposite angle, can simply be defined as a process of giving up individual or community rights on land voluntarily for public usage to include for promoting development project managed either by government agencies or private enterprises. In traditional economy is commonly perceivedas the mean of production, therefore dispossession and forced separation of people from their lands, is a dramatic development policythat mostly done withina post-colonial paradigm: 'top-down' approach (Majumder, 2011). Land acquisition (read: forced land donation) particularly in urban area of developing countries, is a complex process and institutionally consequential. It is proposed then the government need to examine the techniques employed in acquiring the land, the institutions charged with that responsibility, and the methods of financing the acquisition (Berlowitz, 1986). In a predominantly agriculture-based society, land is not only used for food production or a source of livelihood, but also is a symbol of social identity, status, power and wealth. Consequently, loss of land due to various development projects will always become essential point to civil society, especially who are displaced and projectaffected population (PAP). Meanwhile within modernizationperspective, land acquisition is a sound paradigm at pushing economic growth through industrialization.Albeit the impact of land acquisitionwere always questioned stridently. Large-scale displacement, multiple displacements and associated impoverishment, socio-cultural alienation and up-rootedness became points of contention against rampant and greedy land acquisition (Sridhar, 2016).

Land acquisition also exhibits dramatic social ironyresulting greater poverty level and economic inequality, as well as deteriorating conditions for women and children. Most who suffer from hunger in the country are the small and marginal farmers who grow food for the nation. It is easily identified, that continuous structural adjustments, economic reforms and globalization transformed the small and marginal food growing system into a corporate controlled industrial system of agriculture. Land acquisition seriously impact vulnerable groups.In the hope to earn better wages, labor force plunge into the labor market along with their small children and families. They are legally unprotected and economically insecure. They have no insurance coverage nor have any other legislated protective mechanism. Thus, this labor force is exploited with impunity. The incidence of child labor and the deteriorating conditions of women on the farms are increasing (Faizi, 2014). The impact of land acquisition on capital concentration and economic inequality is also sound. Assessment on the pattern of capital concentration in rural India during 1906-2013, revealed that the capital output ratio of land increased to an extreme high for an excessive price hike that led the households to get ambitious for land in the contemporary desirous market. The land- 
rich medium and large farmers were found to accumulate over three forth of all purchases indicating their more contributions to land capitalization. Their major sources of fund were surplus over service income followed by that of agriculture and business. Moreover, continuous capital concentration made the land a commodity, for which a few households with fast-rising service income were even engaged in reckless purchases. However, people with investment opportunities in other highproductive sectors were less eager to purchase agricultural land. (Akanda, 2014).

From public policy and administration perspective, land acquisition is a fragile. State policies on land and public officials are not without flawsin enforcing firmed, just, transparent, participative, effective as well as efficient regulatory policy and administration on land acquisition (Ghatak, 2011). Public officials are not always honestin dealing with land acquisition (Sinha, 2014). Therefore, the concept of "rehabilitation" and "resettlement" known as "R\&R"was introduced to reduce abusive and unjust land acquisition to secure the project affected people (PAPs). It is believed that demands for effective $R \& R$ became stronger over time and was promoted as a prerequisite of land acquisition especially in the projects funded by international donors (Sridhar, 2016). Land Acquisition Rehabilitation and Resettlement (LARR), has been recognized by governments of developing countries, including Indonesia, as one package with land acquisition process. The recognition through legislative process started in early 1990s in order to overcome lapses committed by the administrative officers as well as contending the greed of corporates and other institutions acquiring land. International donors, Asian Development Bank is not the exception, are equipped with strong24principles and procedures ensuring a just and fair land acquisition. It enforces those principles and procedures as non-compromised element of their loan agreement of the hosting countries and governments. Voluntary Land Donation (VLD) was introduced instead of land acquisition expressing clear preferential for individuals and communities who given up their lands for development project. It is assumed that development policy formulation and implementation needs to address those above preference. This study, as stated earlier, is to confirm whether VLD procedures and principles is implemented at community level and how the land utilization for community infrastructures could sustained beyond project closure (ADB, 2013).

\section{RESEARCH METHOD}

Mix method combining both quantitative and qualitative approach is used to conduct a comprehensive post-project evaluation research design.Quantitative design is used during the first stage of the study aiming to conduct project profiling by using field survey as data collection mechanism. Using two-stage sampling technique, thirty-two (32) out of fiftyfour (54) projects were proportionally and randomly selected according to type of donors, project locations, and project categories. In the first step researcher determines $60 \%$ samples representing all project categories and type of donors. Accordingly, there are 32 sample were selected to be studied in Kabupaten Karawang (14 projects), Kabupaten Bekasi (10 projects) and Kota Bekasi (8 projects).In the second step, researcher purposively determines 1 (one) individual representing the main project stakeholder at community level namely land contributors as main sources of information to be surveyed.Survey instrument is divided into three parts, screening questions, demographic characteristics of respondent and perceptional questions (33 questions) distributed to and filled by 32 land donators selected respondents. Screening questions consists of type of project built, legal status of land, total donated land, and the name of surveyors. While demographic characteristics consist of name of respondent, address, phone number, age, gender, religion, level of education, occupation, average of income, and average of expenditure.Qualitative design is used to confirmed survey result, the study purposively determined other project stakeholders i.e. community members as beneficiaries, project facilitators, community leaders (Ketua RT) representing the presence of 
local government officials at community level, and CBOs representatives in project location (if presence in project site) to be interviewed. Independent case study in Kabupaten Bandung is conducted to deepen understanding on how the set procedures and principles are implemented and to have a better insight regarding factors related to project sustainability. In addition to the conducted survey mentioned above, there are three other utilized data collection techniques. Firstly, documentary study verifying all documents related to ICMRMIP in particular subcomponent 2.3. Secondly, in-depth interview with other project stake-holder i.e.community members as project beneficiaries, local community leaders (Ketua RT) representing local government at community level, project facilitators, and members of CBOs (if presence at project site). Interview guide is used for obtaining qualitative information. Thirdly, visit to the project site observing conditions of the built physical infrastructure.

\section{RESULT AND DISCUSSION}

\section{Survey Instruments}

Reliability testing on perceptional questionnaire based on the filled questionnaire revealed with Cranach's Alpha of 0.940 showing that the questionnaires are reliable. In terms of validity testing, 3 (three) out of 33 (thirty three) perceptional questions were not valid. These are Q-8 regarding direct benefit of project for land contributor, Q-21 regarding whether land contributor were asked to sign released document, and Q-24 regarding parties who verify contribution documents. It seems that those three questions are more functional as screening questions with discreet respond rather than questions on perceptions. Therefore those three respected questions were excluded from perceptional questions, but were treated as screening questions instead.

\section{Respondents' Profile}

In term of age, as many as 29 respondents (91\%) are 41 years old or above but in terms of religion, all respondents are Muslims.In terms of educationalbackground, respondents are proportionally distributed among those who hold senior high school or above are 11 respondents(34\%), those who attend elementary school or never been at school at all are 11 respondents (34\%), and those who hold junior high school in between are 6 respondents (19\%) and the rest 4 respondents (13\%) hold higher education degree. Level of education of male is superior to female at high school or below. However, at higher education level both male and female are equally distributed. In term of their occupation, respondents are grouped into four categories. The best three occupational groups are listed as follows housewife 7 (21.9\%), labor accounted for 4 respondents $(12.6 \%)$ and those who has uncertain job accounted for also 4 respondents (12.6\%). This data surprisingly indicates that most respondents are belong to vulnerable group (47.1\%) which was not comply with the set principles discussed in the previous part of this paper indicating those opted for contribution will not fall under the category of poor household or vulnerable household. Distribution of respondents along their monthly income and expenditure, confirms that most of land contributors for the project belong to the vulnerable group. In term of income, $44.5 \%$ of land contributors belong to those who has income 3 million or below (lower group), $11.0 \%$ belong to those who has income between 3 but lower than 5 million (middle group), and the rest $44.5 \%$ belong to the group who has income 5 million or more (upper group). In terms of their monthly expenditure, the pattern is also similar in which respondents were evenly divided into three major categories namely, 38.9\% those at lower than 3 million (lower group), 22.2\% those who has level of monthly expenditure between 3 but lower than 5 million (middle group), and 38.9\% those who has expenditure 5 million and above (upper group). The main purpose of measuring both monthly income and expenditure is to check the 
consistency, reliability and validity of the data. Interestingly, it reveals when comparison between level of income and expenditure across the groups shows that the count and percentage of income for both lower and upper groups are higher than the count and percentage of their expenditure. In contrast, the count and percentage of expenditure for middle group is as twice as higher than the count and percentage of their income. Believing that all information is valid and was resulted from reliable measured, it is justifiable at this point, to probe whether the middle group tends to spend higher than their income compare to the lower and upper groups. Given all information about their income and expenditure have been discussed about above it can be concluded that more than half or $55.5 \%$ of land contributors belong to middle and lower income groups. In term of expenditure $61.1 \%$ land contributor belong to the middle and lower groups. The groups that might considered as vulnerable. Therefore, using education, occupation, monthly income and expenditure as proxy, it is convincingly concluded that the land contributors are dominated by those who are reasonably categorized as vulnerable group for three reasons, religious virtue, social obligations, and long-term economic benefits.

\section{Perceptional Questions}

Perceptional questions are divided into 7 groups of valid questions, these are perception about accepting clear and adequate information about project (Q1-Q7), assessing direct benefit of the project (Q8), determining of project location (Q9-Q16), verifying socioeconomic data (Q17-Q19), administering voluntary land donation properly (Q20-Q24), verifying provision on voluntary land donation properly (Q25-Q26) and assessing gender equality (Q27-Q33).Regarding the clarity and adequacy of information revealed that most of respondents $(82.6 \%)$ respond that information about the project both clear and adequate. It implies two things, Firstly, project facilitators were perfectly complying their assigned tasks. Secondly, the probability of potentially complaining land contributors during project implementation was significantly reduced. Regarding direct long-term, benefit of the project, however, this study does not come up with conclusive result. Q8 did not pass content validity testing. Post survey evaluation with surveyors revealed that the main problem may not be caused by unclear wording or other technical matters, rather it mostly related with uncertain attitude and inability of land contributors to judge the direct benefit of the implemented projects. All surveyors were in agreement at this point that respondents had difficulty to confidently respond to the question. Albeit interesting to note that most of land contributors $(75.0 \%)$ agree and strongly agree about that project will directly benefit them. It is an important note for future project design to clearly indicate and communicate the direct and specific project benefit.

In determining project location as part of participatory project planning and execution, it is shown that most of land contributors agree and strongly agree $(90.7 \%)$ that project facilitators explained clearly about project location. It is also indicated that selection of project location was done by close consultation with land contributors, done intensively and periodically. It is also confirmed that information provided regarding project location was clearly understood by land contributors and therefore it was satisfying. Such conclusive statement is confirmed through average percentage of respondents who are agree and strongly agree (85\%) towards such conclusion above. In terms of social economic background of land contributors is a necessary information in judging whether the land contributors are falling into vulnerable category both socially and economically. Data regarding social and economic profile of land contributors discussed in the earlier part i.e. level of education, occupational background, level of income and expenditure, land ownership and proportion of the donated land, suggested that most of land contributors belong to vulnerable group. Perceptional questions (Q17-Q19) consistently confirmed the findings and explained the reasons. It reveals that only $28.2 \%$ respondents agree that their social background was checked beforehand, 
meanwhile more than $71 \%$ of them neutral, disagree or strongly disagree about the said statement. Most of respondents (71.9\%) are neutral, disagree or strongly disagree confirming that their social economic background was collected by project facilitators. It is also indicated that only $34.4 \%$ of respondent agree or strongly agree upon the statement and most of them (65.6\%) were responding as neutral or disagreethat project facilitators checked their land ownership before executing donation of land for the said community project. In general, it is concluded that $69.8 \%$ of land contributors did not agree that their social economic background was well administered and documented. Therefore, it is convincingly concluded that for future reference, careful check on the social economic background is essential.

In terms of land ownership, it reveals that on average each respondent own 1935.9 meter square of land as they told the surveyor. This study was not able to confirm their information as almost all respondents refused or unable to show their land certificate of entitlement. Although the study have no sufficient legal basis to verify respondents' land ownership, it is noted that the proportion of land donated by respondents is only $2.8 \%$ of which far below $10 \%$ threshold set in agreed land donation procedures and principles. However, it is confidently noted that there were 8 respondents (25\%) who donated their land far above $10 \%$ contribution thresholds. More interestingly there are 2 respondents who gave up the whole land (100\%) to the project, 1 respondent provide $90 \%$ of their land and there is 1 respondent who gave up their land to 66.65. Given all that fact, statistically speaking the average of land donated to the project is as high as $16.2 \%$ of the land they owned. The said information was obtained from the screening question, it implies that land ownership was not once again well administered and documented. In the contrary, the study shows that most of land contributors $(78.1 \%)$ agree or strongly agree that they were requested to fill document related to their donation. Only $15.6 \%$ of respondent who disagree or strongly disagree, or otherwise neutral. It is noted that land donation process was properly administered. The majority of land contributors signed a written documents and they also confirmed the respondents appointed a witnesses who were actually presence to witnesses the process of donation. It is also confirmed that NGOs and local authorities were presence for verifying the signing documents. Despite the fact that the set project procedures was technically complied, it worth to note that findings of the study implied greater problem at land ownership administration as a whole.

Regarding provision on voluntary land donation, it is indicated that voluntary land donation provision was resulted from consensual agreement and information about the selected land for donation was disseminated to broader member of community. This conclusion is confirmed by the study showing that $79.7 \%$ of respondents' agree and strongly agree about the respective matters. It shows that the majority of land contributors (78.1\%) agree and strongly agree that land donation was the result of consensus agreement. Only small number of respondents (12.5\%) who are disagree and strongly disagree with the statement, smaller proportion of respondent (9.4\%) are decided to be neutral. Regarding gender perspective of the implemented projects, it is indicated that most of respondent (69.7\%) agree and strongly agree that the established project was consciously considering the needs and of women in the community. Significant proportion of respondents $(21.9 \%)$ were decided to be neutral and only small number of respondents $(9.4 \%)$ were disagree or strongly disagree. In details, it is clear that gender discrimination is not presence in implemented land donation process, in the sense that women are treated equally as men. In addition it is also indicated that the implemented projects were advantageous of women especially in the field of hygienic, health and education. As a result, most respondents perceived that the compliance of women's need in land donation process was satisfying. 


\section{Important Notes from Kabupaten Bandung}

Case study in Kabupaten Bandung was conducted in Desa Tarumajaya aiming to get a deeper understanding about both compliance towards the agreed procedures and principles in conducting VLD as well as to probe project sustainability beyond project closure. The study all concludes and confirms survey result conducted in Kabupaten Karawang, Kabupaten Bekasi and Kota Bekasi. In terms of compliance more elaborately, the study in Kabupaten Bandung aims to confirm five project principles as the following. Firstly, those opted for donation receive clear and adequate information on the project. Land contributors in Desa Tarumajaya satisfied with the information given about the project. ${ }^{1}$ Kepala Desa Tarumajaya claimed that he was clearly informed and understood about the SAM and SATDALANG project facilities. ${ }^{2}$ Secondly, those who opted for contribution directly benefit from the project. Thirdly, that selection on the project location is undertaken in close consultation with the land/assets owners and communities donating land/assets. FGD involved 26 household head of land contributors confirmed that project facilitators closely consulted them and other community members in selecting project location. ${ }^{3}$ Fourthly, that those opted for donation will not severely be affected by the project. It is concluded that land contributors donated less than $10 \%$ of their land. Although not all contributors stated precise and detail information about the measure of their donation in their signed documents, conducted interview confirmed that contributors will not fall under poor and vulnerable categories. ${ }^{4}$ Fifthly, detailed data on the socio economic background of those opted for donation was collected and reported in the voluntary donation/contribution document.5It

\footnotetext{
${ }^{1}$ Source: interview with land contributors in Desa Tarumajaya.

${ }^{2}$ Source: interview conducted with Mr. A, the Head of Desa Tarumajaya.

${ }^{3}$ Source: conducted interview and FGD with land contributors.

${ }^{4}$ Source: conducted interview with land contributors.

${ }^{5}$ Source: interview with $\mathrm{Mr}$. N, one of land contributor for SANKOM.
}

is also confirmed that the donated land to the project is legally protected by communal property right law (tanah ulayat) that also confirmed by notification letter from village authority. ${ }^{6}$ Sixthly, each donation was verified by the independent party such as NGO or other parties having authority to conduct monitoring.It was found, there were 26 documents represented 26 contributors. Lastly, provisions on voluntary land donation was integrally constructed in the decision making process at the community level and included in the technical guidance that will serve as a reference for the project consultants and facilitators and was disseminated to the communities. ${ }^{7}$ In addition procurement process for SAM and SATDALANG that using the land under conflict, was known and agreed by village authority. ${ }^{8}$ In short, as far as compliance to the set principles are concerned, it is concluded that all principles are followed at the implementation level, except in articulating the need of negotiation and purchasing process with ADB consent for land under conflict.

With regards to project sustainability, three indicators were used for probing whether project might sustain beyond project timeline;long term benefits, institutionalization process and legal protection.In terms of longterm benefits of the project, all project types (SATDALANG, SAM and SANAKOM) are expectedly introducing significant changes in terms of physical access to the facilities, changes in values and orientations, as well as changes in communal health behavior promoting project sustainability. ${ }^{9}$ With regards toinstitutionalization processes Desa Tarumajaya represents a success story of project institutionalization. The structure and personnel in charge for TKM in Desa Tarumajaya are complete and firmed. Initial formal status of TKM was legalized bySK Bupati Kabupaten Bandung No. 443/ Kep 352-Dinkes.

\footnotetext{
${ }^{6}$ Source: interview with Ms. W, one of land contributor for SANKOM.

${ }^{7}$ Source: conducted interview with Mr. C, TKM member responsible for SANKOM.

${ }^{8}$ Source: conducted interview with village authority, Mr. AI.

${ }^{9}$ Source: Laporan Akhir Desa Taruma Jaya Kecamatan Kertasari Kab Bandung 2013.
} 
TKM functions as implementing unit of SAM, SANKOM and SATDALANG. It assumes key roles in managing resources available both inside and outside the village. Socialization about TKM was managed by communicating with village authority, district authority (kecamatan), Dinas Kesehatan Kabupaten Bandung and others. Eventually, TKM is now informally considered as an Infrastructure Management Bureau (Badan Pengelola Sarana-BPS). ${ }^{10}$ It is noted, however, that transformation from TKM to BPS has not formalized yet as confirmed and indicated by our informant. 11

Project sustainability implemented in Desa Tarumajaya was seriously challenged by unresolved conflict between villagers, village authority, PT Perhutani and PT Perkebunan VIII regarding the legal ownership of the land which include the donated land used for community infrastructure.The ongoing conflict has a long story, took an open form since June to December 2013 and remained unresolved to date. The conflict vibrates at grass root level in the common expression such as "...we will keep fighting, up to the court as necessary, because we know exactly the conditions, the problem of land in Desa Tarumajaya". 12It revealed that the greatest project challenge in Kabupaten Bandung was not about complying project implementation towards a set procedures and principles agreed by both ADB and GOI, but mitigating project sustainability through conflict resolution on land among committed parties and firmed legal protection of the established project institutions and assets as well as maintaining long-term project benefit for main beneficiaries. This fact is also true for Kabupaten Karawang, Kabupaten Bekasi and Kota Bekasi.

\section{CONCLUSIONS AND RECOMMENDATIONS}

It is confidently concluded from both field survey and case study that, firstly, those opted for voluntary land donation under study fall under the category of poor household or

\footnotetext{
${ }^{10}$ Source: guided interview with TKM Leader, Mr.AD.

${ }^{11}$ Ibid

${ }^{12}$ Source: interview with villagers.
}

vulnerable household measured by their education background, occupation, monthly income and expenditure as proxy. Secondly, the study confidently concludes that those who opted for donation were requested to fill document related to their donation. However, procedural compliance did not associate with one of the set principle indicating that those who opted for donation will not be severely affected. Thirdly, it is interesting to note that majority of those who opted for donation $(75 \%)$ believed that the project will directly benefit them. Albeit this study has not much confident to drag conclusion regarding the matter. Fourthly, this study confidently concludes that those who opted for land contributions received clear and adequate information about the project. Fifthly, it is convincingly concluded that gender discrimination was not exist in land donation process under study, in the sense that women are treated equally as men, the implemented projects were advantageous of women especially in the area of cleanness, health and education. It is also indicated that the implemented projects were advantageous of women especially in the field of hygienic, health and education. Sixthly, the study shows both positive and negative aspect of the project. On one side, clear information shared by those who opted for donation, optimistic perception about direct benefit of the project, and gender inclusion in the project would likely increase the probability of project sustainability beyond project closure. On the other side, inadequate assessment and documentation of social and economic back ground as well as on land ownership of those who opted donation, would probably lessen project sustainability and increase the possibility of them falling into deeper poverty and vulnerability. Finally, project sustainability face three serious challenges as demonstrated in Kabupaten Bandung, interrupted long-term benefits, insufficient legal protection of land ownership and project assets as well as incomplete institutionalization process.

Given all findings, this study come up with numbers of recommendations. CDD is not merely a pragmatic approach, process nor 
technical mechanism for delivering development policies or programs, but also provides solid theoretical and methodological ground for understanding project implementation as a scientific endeavor. Therefore, providing academic training is necessary. Along this line some serious flaws were found in the implementation of VLD. It is recommended that the implementation of VLD should not only focus on the short sighted administrative procedures, but ultimately dedicated to achieving substantive principles by delivering determined outputs as well as intended long-term positive impacts of the project. Among others there are at least four critical points need to be improved for future projects. Firstly, the project needs to run careful assessment on social economic background that might necessary for understanding and predicting economic aspect of the program. Secondly, the project needs to closely follow the set and agreed principles so that the project risk can be minimized. Thirdly, the project needs to develop systematic and clear project documentation, especially regarding legal status of donated land and its donation process. The limit of this study was conducted after the project closure, so that was unable to assess the actual implementation of the project especially in explaining procedural compliance, Finally, to deepen theoretical understanding as well as to enrich empirical evidence, further case study need to be conducted for future reference. ${ }^{* * *}$

\section{ACKNOWLEDGEMENT}

This paper is considered as an academic paper that was essentially crystalized from the previous project report on land donation verification implemented in sub-component 2.3 ICWRMIP. Author extend his gratitude to the project for the opportunity and financial support, to LPPM Unpar for facilitation and assistance, to i-cord team who were always push every efforts beyond the limit of expectation.

\section{REFERENCES}

Asian Development Bank. (2014). Term of Reference for Land Donation Verification.

Asante, KwadwoAdusei. P.H. (2012). Theories in community-driven development operations: a case study of Ghana local government system.. European Journal of Business and Social Sciences, 1(5), pp. 8389.

Katz, S.A. (2003). Community-Driven Development. In: P. D. et.al, ed. Community-Based Development General, the World Bank Group.

Smith, A and Frank Flo. (1999). The Community Development Handbook; A Tool To Build Community Capacity. Canada: Human Resources Development Canada (HRDC), Labor Market Learning and Development Unit.

Tan, A. (2009). Community Development Theory and Practice: Bridging the Divide Between 'Micro' and 'Macro' Levels of Social Work. Indianapolis: NACFW Convention, p.6.

Mathbor, G. (2008). Effective Community Participation in Coastal Development. Monmouth University, Lyceum Books.Inc.

Sridhar, V.B.G. (2016). Editorial: special issue on land acquisition, rehabilitation and resettlement in India. Journal of Land and Rural Studies, 4(1), pp. 1-2.

Majumder, B. (2011). Accumulation by dispossession and radicalism in circulation in India: role of the state. Journal of History and Social Sciences, July-December.II (II).

Berlowitz, A. J. (1986). Land acquisition in developing countries. Fordham International Law Journal, 10(4).

Sridhar, V.B.G. (2016). Editorial: special issue on land acquisition, rehabilitation and resettlement in India. Journal of Land and Rural Studies, 4(1), pp. 1-2.

Amir Afaque Ahmad Faizi, T. M. S. (2014). Contract farming and gender relations in India. Journal of Land and Rural Studies, p. 191-214.

Akanda, A. (2014). Capital concentration on land ownership in rural Bangladesh. 
Journal of Land and Rural Studies, pp. 215-232.

Ghatak, Maitreesh, P. G. (2011). The land acquisition bill: a critique and a proposal. Economic \& Political Weekly EPW, 8th October.pp. 65-72.

Sinha, B. (2014). Land Reforms: evidences of reversal in Orissa. Journal of Land and Rural Studies, 2(2), p. 171-190.

Sridhar, V.B.G. (2016). Editorial: special issue on land acquisition, rehabilitation and resettlement in India. Journal of Land and Rural Studies, 4(1), pp. 1-2.

Asian Development Bank. (2013). www.adb.org, http://www.adb.org/documents/safegua rd-policy-statement

Asian Development Bank. (2013). www.adb.org, http://www.adb.org/documents/safegua rd-policy-statement 